\title{
Sort \\ En reparerende læsning af den vrede og tykke (kvinde)krop
}

\section{Af Camilla Bruun Eriksen}

\section{Abstract}

Sort. A reparative reading of the angry and fat (female) body

Instead of a purely aesthetic state or medical condition fat scholar Kathleen LeBesco (2004: 1) suggests considering fatness as performative and a political situation. Based on the novel Sort (2012) by Kamilla Hega Holst this article examines and discusses LeBesco's thesis; that the fat body by virtue of its culturally created position as 'deviant' and 'abnormal' holds a special ability to evoke 'terror' and disturb social order. Through both reparative and paranoid readings, and by applying Sara Ahmed's figure The Feminist Killjoy as well as Lee Edelman's conceptualization of queer futurism, the possibility of reading the novel's fat protagonist as a queer character who actively and consciously resists social demands for a happy future is considered. Furthermore, 'the body as battleground', agency, as well as the fat body's potential to oppose normalizing practices of embodiment is discussed.

\section{KEYWORDS}

fat, queer reading, feminist killjoy, queer futurism, embodiment, literature.

Camilla Bruun Eriksen er ph.d.-stipendiat ved Institut for Kulturvidenskaber, Syddansk Universitet og en del af forskningsgruppen SUKK, der blandt andet beskæftiger sig med sundhed, køn og krop. Artiklen er en del af en ph.d.-afhandling om populærkulturelle fortællinger om den tykke krop. 
"Celebrating fat as sexy is an outrageous provocation in a society where fat women are reviled" Don Kulick, Fat. The Anthropology of an Obsession (2005: 85)

"The story of feminism is thus a history of making trouble" Sara Ahmed, The Promise of Happiness (2010: 60)

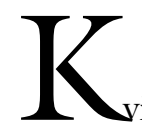

gav i 1970'erne kroppen en ny betydning og den forste udgave af Kvinde kend din krop fra 1975 varslede et politisk opgør på stort set alle tænkelige fronter; økonomisk, socialt, sundheds-, værdi-, og uddannelsespolitisk. Kroppen blev, som det populært hedder, gjort til en kampplads og ansvaret for kroppen til et konkret, praktisk og aktivistisk projekt (Rosenbeck 2006, 106). Kvindekroppen, der var blevet underlagt især et medicinsk og naturvidenskabeligt blik og sprog, skulle generobres og behandles som en kulturel og historisk situeret størrelse fremfor en udelukkende biologisk og naturlig entitet (Ibid.). Feministiske strømninger og teorier om kroppen fulgte efter: Både de, der hævdede, at kvindekroppen var en adgangsgivende billet til et særligt (søster)fællesskab og dermed bestemte politiske interesser (fx Rødstrømpebevægelsen, radikal-, marxistisk- og socialistisk feminisme og til dels 'fransk feminisme'/sexual-difference-skolen) og senere de, der i højere grad satte spørgsmålstegn ved, at kvindekroppen skulle kunne rumme universelle erfaringer på tværs af kategorier som fx race, klasse og seksualitet (fx postkolonial og queer feminisme) (Lykke 2008, 76-77, 113). Dengang som nu er overvejelser om agens, kontrol og viden blevet indskrevet i (kvinde)kroppen og dermed gjort til udgangspunkt for politiske kampe.

Med afsæe i romanen Sort (2012) af Kamilla Hega Holst berører denne artikel (nogle af) de feministiske og kropspolitiske diskussioner, der næsten per automatik synes at rejse sig, når det drejer sig om en tyk kvindekrop. Romanens fortælling om den meget tykke protagonist, Sanne, rammesætter på interessant vis den tykke krop som en dybt polariseret politisk kampplads, hvor slag om sundhed og skønhed, agens og subjektivitet udkæmpes og udkrystalliseres. Sort er således udvalgt, fordi fortællingen om Sanne er fyldt med sprækker og revner, der åbner op for muligheden af at læse den tykke krop frem som en politisk situation og en størrelse, der (muligvis) kan yde modstand mod et traditionelt og snævert kvindeligt kropsideal, der stigmatiserer ikke-normative kroppe (Bordo 1993).

I tillæg til feministiske teoretiseringer af kroppen indskriver artiklen sig i et fat studies felt, der med "the language, culture and theory of civil rights, social justice and social change" (Cooper 2010, 1020) sigter på at problematisere og destabilisere en traditionel og biomedicinsk forståelse af 'fedme' ved blandt andet at insistere på, at tykhed handler om mere og andet end biologi, hormoner og fedtvæv (Bacon 2010; Cooper 2010; Lupton 2013). Med artiklen tilslutter jeg mig en forståelse af tykhed lig den, som fatforsker Kathleen LeBesco præsenterer i Revolting Bodies? The Struggle to Redefine Fat Identity (2004). Fremfor en enten udelukkende xstetisk eller medicinsk tilstand må den tykke krop forstås som en performativ og relationel kategori influeret af blandt andet historiske, politiske, socioøkonomiske og kulturelle tankesæt og strømninger (Ibid. 1). En sådan tilgang har imidlertid også mødt kritik. Blandt andet fra kultur- og kønsforsker Elspeth Probyn, der anklager fat-feministiske analyser af tykhed for at lægge alt for stor vægt på positiv representation og 'overflade' og for at un- 
dervurdere og udviske de konkrete og negative konsekvenser, der følger i kølvandet på tykhed $\mathrm{i}$ form af sygdomme og sundhedsmæssige følgevirkninger:

An over-reliance on a simplistically framed notion of representation has produced a body of argument that can only focus on the body as image. Drawing on much the same methods as other identity politics, including queer, the end point is seen as accepting and celebrating super-sized female bodies (Probyn 2008, 402).

I stedet for at fejre den tykke krop tilskynder Probyn at se nærmere på, hvordan tykhed - forstået som en kropslig tilstand influeret af køn, klasse og race - er tæet sammenhængende med fx verdens madproduktion. Mens verdens madproduktion helt sikkert kunne (og burde!) underlægges et mere grundigt feministisk perspektiv, end den hidtil er blevet, er det ikke en anbefaling, jeg kommer til at følge op på med denne artikel. Tværtimod. For selv om formålet med denne artikel ikke (direkte) er at fejre den tykke krop, spørger jeg alligevel til potentialet i den. Jeg ser derfor til poststrukturalistiske feministiske teorier om kroppen (fx Butler 1993; Grozs 1994; Søndergaard 1996), men i særdeleshed til LeBesco, der hævder, at den tykke krop i kraft af sin kulturelt skabte position som 'afvigende' og 'abnorm' rummer et særligt og produktivt queer potentiale til at vække ubehag, forstyrre social orden og dermed modsætte sig normaliserende praksisser for kropslighed:

If we think of revolting in terms of overthrowing authority, rebelling, protesting, and rejecting, then corpulence carries a whole new weight as a subversive cultural practice that calls into question received notions about health, beauty, and nature (LeBesco 2004, 1).

Et potentiale jeg mere konkret vil efter- prøve og diskutere i denne artikel ved at lade den tykke krop udgøre et kritisk afsæt for mere vidtgående spørgsmål om, hvordan de fortællinger, der knytter sig til tykhed i romanen Sort, griber ind i, forhandler og udfordrer normative forestillinger om $\mathrm{fx}$ seksualitet, begær, agens og fremtiden.

\section{PARANOIDE FORSøG PÅ REPARATION}

Med både Between Men. English Literature and Male Homosocial Desire (1985) og Epistemology of the Closet (1990) udviklede queerteoretiker Eve Kosofsky Sedgwick en række betydningsfulde og brugbare analyseværktøjer med det formål at afsløre homofobi som et grundlæggende og strukturende vestligt samfundsprincip. Analyseværktøjerne blev samlet set til en paranoid lesestrategi, der har til formål at belyse magtens mange virkemåder. Senere i et essay med den famøse titel: Paranoid Reading and Reparative Reading, or, You're so Paranoid, You Probably Think This Essay is About You (2003) argumenterer Sedgwick imidlertid for, at en paranoid læsestrategi i nogle tilfælde desværre blot "mimer" og dermed reproducerer de strukturer, den ellers er skabt til at blotlægge. Som et alternativ til den efterhånden mere eller mindre 'queerklassiske' paranoide læsestrategi tilbyder Sedgwick derfor en reparerende lesestrategi inspireret af blandt andre affektteoretiker Silvan Tomkins og psykoanalytiker Melanie Klein (se Sedgwick 2003: 136-138). Modsat den paranoide læsestrategi, der, ifølge Sedgwick, altid finder og afslører det, den leder efter i teksten, har den reparative læsestrategi til formål at finde åbninger, modstemmer og muligheder i teksten. På baggrund af Sedgwick opsummerer kønsog affektforsker Anu Koivunen en reparativ læsestrategi som:

a critical attitude that invests in hope, seeks positive affect, surprise and wonder and, therefore, assumes the risk of vulnerability" (Sedgwick 2013, 23) 
Altså en tilgang, der muligvis gør den reparative læsestrategi mere skrøbelig end den paranoide, men givetvis også mere modig $\mathrm{i}$ sit forsøg på at læse med teksten. Jeg er imidlertid enig med Koivunens kritik af Sedgwick, når hun videre beskriver, hvordan forestillingen om, at læseren/forskeren frit og helt uden konsekvenser skulle kunne vælge mellem et reparerende og et paranoidt blik på en tekst, er en privilegeret position forbeholdt de få (eller måske ligefrem en illusion), der samtidig reproducerer en uheldig dikotomi mellem 'stærk' og 'svag' teori og dermed også 'god' og 'dårlig' videnskab:

In these interpretations, paranoid and reparative readings are considered fundamentally different. One as a negative, destructive form of criticism; an amalgam of programmatic and ideological approaches that instead of producing "new knowledge" reproduces old truths, the same, which we already know. The other, again, open, positive, sensitive, healing, productive and innovative. Alongside the opposition of good versus bad scholarship, a distinction between ethical and unethical approaches emerges (ibid., 25). ${ }^{1}$

Ligeledes er jeg enig med affektteoretiker Sara Ahmed, der gennem analyser af blandt andet racisme og hvidhed har argumenteret for potentialet $i$ (og nødvendigheden af) at fastholde en vred og paranoid læsestrategi (2010, 79-88). Når afvisningen af 'negative' og 'ubehagelige' følelser som vrede, paranoia, surhed og skuffelse sker med henvisning til nødvendigheden af at opretholde 'den gode stemning', risikerer vigtig og valid kritik at blive opgivet på bekostning af et normativt og samfundsmæssigt krav om glæde og positivitet (Ibid.). Mit ærinde er derfor heller ikke et 'traditionelt' kropspositivt et af slagsen, der sigter på at tilskrive den tykke kvindekrop mere positive egenskaber på trods af sundheds- og samfundsmæssige normer, der ellers næsten udelukkende tildeler den andre og mere negative af slagsen. ${ }^{2}$ Tværtimod er formålet med mine læsninger at fastholde og undersøge den udsatte og dobbeltmarginaliserede position, som den tykke kvindekrop befinder sig i, fordi den ikke blot er tyk, og derfor ofte tilskrives en række negative egenskaber, men også kvinde i en stadig mandsdomineret og patriarkalsk verdensorden (Bordo 1993).

På baggrund af ovenstående ligger en dekonstruerende og paranoid læsestrategi muligvis ligefor. Jeg ser imidlertid et potentiale $\mathrm{i}$ romanens beskrivelser af kroppen, der synes at kalde på anderledes læsemuligheder, end dem en udelukkende paranoid læsestrategi kan tilbyde. Det er dette potentiale, en mere reparativ læsning skal åbne op for, hvorfor jeg løbende i min analyse vil forsøge at gå mere reparerende til værks uden dog at kunne tilbyde vandtxtte skotter mellem mine paranoide og mere reparative læsninger. I tråd hermed er det værd at understrege, at analyser ikke er løsrevne størrelser situeret i et vakuum. At foretage en reparativ læsning af en tyk kvindekrop, der samtidig indskriver sig i en rigid kropskultur, der så tydeligt kæder tykhed sammen med usundhed og sygdom, som det er tilfældet i Danmark anno 2017, er en udfordring, der kræver (politisk) vilje og lyst et aspekt jeg vil diskutere yderligere blandt andet ved at inddrage begreberne gladesdrab og queer futurisme.

\section{TYNGDEN FRA KROPPEN}

Kort fortalt er romanen Sort (2012) hovedsageligt bygget op omkring protagonisten Sanne og hendes minder om forældrenes skilsmisse, hendes parforhold med kæresten Jesper, der seksuelt tænder på at fede Sanne op, deres sexliv, Sannes mange vredesudbrud og hendes fars kræftsygdom, der udvikler sig og betyder, at Sanne og Jesper flytter ind i Sannes barndomshjem for at passe ham den sidste tid inden hans død en begivenhed, der også afslutter romanen. Sporadisk spredt mellem fortællingerne 
dukker dokumentarisk materiale op i form af venstreorienterede læserbreve skrevet af Sanne og optegnelser, noter, journaler og medicinoversigter, der dokumenterer farens liv. ${ }^{3}$ Beskrivelser af Sannes krop er mange og ofte tvetydige - de vidner om både den smerte, der kan være forbundet med en meget tyk krop, men også om det store begær den rummer, og som Jesper nærer for den:

Sanne er vokset ud af sine gamacher. Hun udskifter dem først, når syningen går op.

Jesper er ekstra opmærksom på hende i dagene, inden de sprækker. Det udvidede stofs gennemsigtighed. Elastikkens forsvinden ind $\mathrm{i}$ fedtet, maven der buler ud nedenunder. Hendes fyldige skød. Hun klæder sig i korte, stramtsiddende trøjer. Brysterne flyder frit under stoffet, gnider mod maven. Det svier. Jesper vasker og tørrer hende. Plejer huden med salve.

- Lidt forover, beder han.

Hun læner sig frem. Svajer i ryggen, mærker tyngden fra kroppen mod gulvet. En værkende lænd. Står dér (2012, 152).

Og det er ikke kun Jesper, der begærer Sannes krop. Sanne har filmet sig selv (og gør det senere med hjælp fra Jesper) og lagt videoerne på nettet. I videoerne løfter Sanne i sine deller og lader dem falde på plads, hun gisper efter vejret, spiser og slår sig på sin udspilede mave. Grænserne mellem mad, sex og begær flyder således sammen i flere af fortællingerne om Sannes og Jespers forhold, som her, hvor Jesper har lavet mad:

Han har hældt rødvin op i glassene, skål, siger han. Hun drikker. Han tilbyder at skære maden ud for hende. Vil gerne hjælpe hende, made hende, stikke sin tunge ind i hendes mund. Smagen af sovs. Han skærer kødet ud. Kartofler, pastinak og selleri. Han dypper kødet i sovsen, stikker gaflen ind i hendes mund. Hans rejsning er intimiderende bag buksestoffet. Hun tygger og sluger $(2012,182)$.
Det er denne komplekse og sjældent entydige fremstilling af Sannes krop og seksualitet, der åbner op for muligheden af en mere reparerende læsning af Sort. For selv om skildringen af Sanne er anti-normativ (her forstået som ikke-mainstream) og tydeligt trækker på en populærkulturel forestilling om den tykke kvinde som ude af stand til at styre sit begær såvel som sin appetit (Bordo 1993), så fortælles Sannes krop interessant nok hverken frem som aseksuel eller sygelig. Tværtimod er det netop Sannes enorme og næsten grænseoverskidende massefylde, der gør hende til en begærlig og begærende krop. Et eksempel herpå er beskrivelsen af, hvordan Jesper indhyllet $i$ "en lugt af sved og betændelse" bader Sanne, vasker hendes krop fri for "gulligt sekret" og plejer hendes mange røde, ømme sprækker under dellerne. Den sproglige beskrivelse af Sannes krop er således i højere grad gjort frastødende end flatterende, og har ikke meget tilfælles med en traditionelt erotisk iscenesat kvindekrop. Alligevel er beskrivelsen tydelig seksuel, meget intim og nærmest xggende som et udforskende forspil:

Han vender hende en smule om på siden så han kan vaske hendes ryg. [...] Ind mellem balderne. Han presser dem fra hinanden med fingrene, vasker omhyggeligt omkring endetarmsåbningen. [...] Han stryger kluden ned mod skeden, sætter sig på hug og skiller skamlæberne ad. Der sidder lidt toiletpapir fast, som han fjerner med to fingre. Dupper med kluden. Han stikker sin tunge op i hende, slipper med sin hånd og lader lår og balder omslutte ham (2012: 15-16).

At Sannes seksualitet og begær fylder meget i romanen er i det hele taget en pointe, der er værd at notere sig alene fordi erotiske og seksuelle populærkulturelle repræsentationer af den tykke krop ellers som regel er meget sparsomme, nok særligt fordi:

(...) the fat woman is removed from the scheme of attractiveness given that her size vio- 
lates traditional ideas of feminine iconography (Richardson 2010, 83).

I stedet er der tradition for at fremstille den tykke krop som ude af stand til at have et tilfredsstilende sexliv eller simpelthen som decideret aseksuel (Asbill 2009; Pyle \& Loewy 2009; Richardson 2010). Fremfor at skildre Sanne som uinteresseret i sex beskrives hun tværtimod som en yderst seksuel kvinde, der i høj grad begxrer sig selv og sin krop:

Når hun slår sig selv, sender det bølger igennem hende. Det kan ses på optagelserne, kroppens rystelser. Hun spiser, imens hun filmer, propper sig til maven presser mod hendes skød. Slagenes acceleration. Ofte kommer hun. (Holst 2012, 50).

Sanne og Jespers forhold bygger således også i høj grad på sex og begær - noget der tydeligt har defineret deres relation siden deres første møde:

Hun havde aldrig tidligere set på en mand med et blik, der bad ham trænge ind i sig. Hun havde altid klaret det selv og havde forestillet sig, at hun ville blive ved med det.

Jesper tog hende bagfra op af et træ. Hun var 30 år gammel. Det var forste gang, hun mærkede følelsen af nøgen hud mod sin. Mrrkede en andens tunge mod sin. En stiv pik oppe i sig.

- Igen, bad hun. (Ibid., 5l).

Skildringen af Sannes seksualitet og begær bryder således i den grad med fordomme om, at tykke kroppe slet ikke kan, vil eller bør have sex og rammesætter i stedet Sanne som en yderst handlekraftig og viljestærk kvinde, der trods sine mobilitetsproblemer og en gennemsnitlig set sen seksuel debut, ikke lider under sin feeders ${ }^{4}$ vilje og magt og da slet ikke seksuelt, hvor Sanne ind imellem er den, der "knepper Jesper" (Ibid., 170) og med sin store vægt dominerer ham - noget der ellers traditionelt set er forbun- det med heteronormative forestillinger om mandens aktive og aggressive seksuelle rolle i mødet med den mere passive kvinde.

I forsøget på at læse med teksten er det desuden værd at bide mere overordnet mærke i de både nuancerede og til tider tvetydige beskrivelser af Sanne, idet populærkulturelle repræsentationer af den tykke (kvinde)krop ellers ofte reducerer den til en endimensionel og stereotyp figur (Murray 2008). Blandt velkendte tykke arketyper kan nævnes: Den sjove og ofte uheldige sidekick til den slanke helt ( $\mathrm{fx}$ 'Hjørdis' fra tv-serien Rita eller Keld' fra Olsenbandenfilmene), Den ensomme og udstødte stakkel (fx 'Fede Dorit' fra børneanimationsfilmen Terkil $i$ knibe, Mulle' fra romanen/ ungdomsfilmen Zappa eller 'Tykkesen' fra romanen/filmen Det forsømte forair, der dog senere udvikler sig til:), Den magtfulde og grådige (forretnings)-mand, der med en symbolsk struttende vom fremviser sin velstand. Skildringen af Sanne som både veluddannet, hidsig, viljestærk, liderlig, intelligent, politisk, egoistisk, voldsom og omsorgsfuld gør hende imidlertid til en yderst mangefacetteret og kompleks figur, der yderligere bryder med udbredte forestillinger om, at dét at indgå i et feeder/feedeeforhold altid er et udtryk for undertrykkelse og udnyttelse, ${ }^{5}$ og at tykhed skulle være et udtryk for uvidenhed om kost og motion og mere generelt: uddannelse. ${ }^{6}$ Beskrivelserne af Sannes krop og hendes forhold til sine nærmeste indbyder således til fornyet diskussioner af, hvordan agens, subjektivitet og viden forstås i relation til tykhed - diskussioner, der på ny kan siges at gøre kroppen til en politisk kampplads.

\section{SMÅ FORLØSNINGER}

Det er næsten som om bogens overordnede kritik er blevet kogt ned og smidt ind på side 154 i form af modsvar, skrevet af Sanne, på et læserbrev vedrørende regeringens forsøg på at forlænge den danske befolknings levetid: 
Det er bestemt værd at overveje (...) med hvilken begrundelse man så krampagtigt fastholder og forsøger at forlænge livet. Personligt har jeg sat mig for at modarbejde den konstante optimering af kroppen som en falsk omsorgsfuld varetagelse af det enkelte individ, der reelt set bunder i et politisk ønske om at forøge befolkningens samfundsmæssige nyttefunktion. Hold dig sund og rask og evigt mobil og fleksibel, så vi er fuldstændig sikre på, at du kan yde dit i den cirkulerende produktion af varer og subjekter. Så skide være med, hvor tomt og meningsløst dit liv ellers måtte synes. Lev et langt politisk lydigt og økonomisk nyttigt liv som passiviseret forbruger, pakket ind i tryghed så vi er fuldstændig sikre på, at oprøret aldrig når længere end et muligt skingert læserbrev (Holst 2012, 154).

Sannes sarkastiske læserbrev og hendes personlige forsøg på at modarbejde den konstante optimering af kroppen, gør ikke bare Sanne til vred og temmelig kynisk skribent, men også at hun kan læses som en kropsaktivist, der kritisk spørger ind til normative og disciplinerende kropspraksisser og -forståelser. Noget tyder desuden på, at Sanne, der er humaniorastuderende og i gang med sit speciale, med stor sandsynlighed har stiftet bekendtskab med Foucault og hans magtanalytik. Sanne synes således meget enig i en Foucauldiansk pointe om, at modelleringen og udformningen af kroppen er et magtpolitisk anliggende, der etablerer grænser og normer for, hvad der kan genkendes og tolereres som en 'rigtig' og ønskværdig krop (Foucault 1994). Læserens viden om Sannes meget store krop betyder samtidig, at endnu en udbredt fordom punkteres; nemlig den at tykhed aldrig er et aktivt valg, men tværtimod en uheldig og trist konsekvens af $\mathrm{fx}$ en 'usund livsstil'. Sannes læserbrev planter således ideen om, at Sanne med sin meget høje vægt slet ikke opfatter sig selv som et offer eller sin krop som 'problematisk', men i stedet bevidst bruger den til at modsætte sig dogmer om at være effektiv og sund. Sanne kan dermed læses frem som mere og andet end en vred læserbrevsskribent og Foucault-inspireret kropsaktivist; nemlig som en feministisk glædesdræber, der peger på samfundsmæssige uretfærdigheder og kropslige privilegier.

Med figuren feministisk glædesdræber beskriver Ahmed det potentiale, hun ser i den sure, vrede og forbitrede feminist, der med vilje ødelægger de andres glæde og den gode stemning, når ellers den gode stemning hviler på og dækker over eksempelvis sexisme, racisme, homofobi, etc. (2010). "Does the feminist kill other people's joy by pointing out moments of sexism?" spørger Ahmed og svarer retorisk: "Or does she expose the bad feelings that get hidden, displaced or negated under public signs of joy?" (Ahmed 2010, 65). Den feministiske glædesdræber er dermed en figur, der

exposes the inequalities, unfairness, or unhappiness of others as a precondition for the happiness of the privileged, making the norm momentarily uncomfortable for those who otherwise never notice the privileges they enjoy (Frederiksen 2014, 8).

Det feministiske glædesdrab handler med andre ord om at holde fast i vreden, frustrationen og surheden som en strategi, der kan afsløre uretfærdigheder og gøre normen 'ubehageligt' opmærksom på sin egen uforstyrrethed (Ibid.). Ahmed noterer sig imidlertid, at rollen som glædesdræber ikke er let: Den vrede feminist anses ofte for at være den, der bringer den dårlige stemning med sig. Således misforstås feminister generelt som værende grundlæggende sure og vrede i stedet for nogle, der er gjort sure og vrede af de uretfærdigheder, de ser og oplever (Ahmed 2010, 65).

At læse Sanne som en feministisk glædesdræber betyder, at hendes hyppige og ind imellem voldsomme vredesudbrød ikke længere kan afskrives som 'hysteriske' og hidsige ligegyldigheder. I stedet kan de 
læses som en reaktion på den dårlige stemning, der konstant omgiver den tykke krop, som da Sannes tidligere klasselærer oven på et vredesudbrud foreslog at isolere Sanne af hensyn til Sanne selv og den gode stemning i klasseværelset: "Det går ud over de andre børn, sagde hun. - Jeg tror også, at Sanne bedst kan lide det sådan, uden for mange øjne på sig” (Holst 2012, 36). Som glædesdræber er Sanne således heller ikke grundlæggende vred, men bliver det, når hun eksempelvis læser avis:

Artiklerne, hun læser, medfører trykken for brystet, sammenbidte tænder, hændernes sitren. Hun læser højt inde i sig selv, tungen bevæger sig bag tænderne. Journalistiske vinkler. Udsnit af liv. Skamkneppede prostituerede, overvågning og mikrolån. Forebyggelseskommissioner. PET. (Ibid., 48)

Sannes vrede, som artiklerne afføder, udmunder i læserbreve skrevet på et øjeblik under højlydt råben:

Sommetider banker naboen på væggen. Så stopper Sanne med at råbe, hænderne ryster stadigvæk. Kæben gør ondt. Hun er særlig følsom i fingerspidserne, tasteturet er koldt, 1000 enheder inklusiv mellemrum. Hun holder sig instinktivt inden for læserbrevets anslagsbegrænsninger, får afløb på et øjeblik (Ibid.)

Frem for at være "ugennemtænkte" og "iltre" udbrud, som faren kalder dem (Ibid., 72), foretrækker Sanne at tænke på sine læserbreve som "uredigerede", "et øjebliks acceleration" og som små forløsninger (Ibid.). Med sine vrede læserbreve af næsten seksuel karakter protesterer Sanne over alt fra sexistiske licens-betalte tv-programmer (Ibid., 125) til debattøren Uwe Max Jensens tolkning af radikal-feministen Valerie Solanas' attentatforsøg på Andy Warhol (Ibid., 62). Sannes protester kan læses som konkrete forøg på at ødelægge fællesskabets gode stemning og lykke, når den forekommer på bekostning af andre, der står udenfor - som her i et indlæg om Sandholmslejren:

Således kan vi under overvågede og ordnede forhold skille os af med utilpassede og uvelkomne individer og endda finde accept af denne udryddelse hos samfundets borgere gennem en systematisk installerende normmæssighed, der er lige så ekskluderende, som den er selvregulerende (Ibid., 46).

Det er ikke kun Sannes kritiske læserbreve, der kredser om emnerne regulering og disciplinering: I sine studier er Sanne optaget af individets forsøg på at unddrage sig sproglige og samfundsmæssige strukturer (Ibid., 86-87) og i sociale sammenhænge gør Sanne, hvad hun kan for at modsætte sig organisering, disciplinering og sociale spilleregler - som når hun fejer vådlagnet til side og pisser i madrassen i protest over Jespers forsøg på at organisere og rydde op i lejligheden. Sanne vredesudbrud kan da læses som et aktivt våben $\mathrm{i}$ kampen mod alt det, Sanne finder problematisk, og som et udtryk for agens og politisk vilje.

Gennem fortællinger om Sannes store begxr, hendes sexliv og vrede og ikke mindst hendes krop, der gang på gang overskrider sig selv i størrelse og form, rejser romanen spørgsmål om, hvad der overhovedet er at betragte som sundt, begærligt, sexet og ønskværdigt. I et reparativt perspektiv bliver Sannes tykke krop til en politisk kampplads, hvor normer for kropslighed, seksualitet og agens forhandles og udfordres. Når Sanne tildeles rollen som feministisk glædesdræber, opstår der således en temmelig unik mulighed for at læse den tykke krop frem som en krop, der aktivt, bevidst og velovervejet yder modstand mod forestillingen om 'den rigtige, slanke, sunde og fleksible krop' ved at forstyrre den gode stemning, der omkredser den. Den reparative læsning, der her vokser ud af den tykke krops særlige evne til at vække ubehag, er imidlertid svær at fastholde, fordi en 
række problematikker, som jeg nu vil se nærmere på, konstant dukker op.

\section{SYGELIGHED}

Det er Jesper, der passer, plejer og muliggør et liv for Sanne, hvori hun ikke behøver foretage sig meget andet end at spise og skrive. Jesper forsørger dem begge, han arbejder, handler ind, rydder op, laver mad, gør rent, farver hendes hår og puder Sanne op i sengen, mader, barberer og vasker hende. Flere passager indikerer imidlertid, at Sannes krop reelt er ved at give efter og op for vægten:

Hendes håndled værker. Hænderne er svedige mod cisternen. Knæene og hoften gør ondt.

Selv i hvile. Smuldrende knogler, udtyndet væv og porøse lameller. Knogleskørhed? (ibid., 183).

Jespers manglende interesse for Sannes mulighed for $\mathrm{fx}$ at kunne bevæge sig omkring på egen hånd sammenholdt med de mange beskrivelser af hans store lyst til Sannes enorme og voksende krop betyder, at han kommer til at fremstå som en mand, der er mere optaget af sit eget seksuelle begær end sin kxrestes mulighed for at overleve det - et karaktertræk, der gør Jesper temmelig usympatisk. Med fortællingen om, hvordan Jesper med meget travle forældre blev forsømt og voksede ensomt op i Bangkok mere end indikeres det samtidig, at han af den grund meget tidligt udviklede en forsmag for det seksuelt 'aparte'. Logikken heri synes at være, at Jesper, fordi han så ofte var overladt til sig selv, er blevet noget sær - et karaktertræk, der afspejler sig i hans seksualitet:

Jesper sad blandt publikum. Han kunne stadig lugte deres [sexarbejderne, der tidligere på dagen har glatbarberet og haft sex med Jesper] dagssved på sig. De spredte benene ud mod publikum, skød bolde ud af deres fisser, sådan et potentiale, en byge af bordten- nisbolde ud i lokalet. Jesper greb boldene, tog dem med sig hjem, gemte dem i kisten med breve og andet af værdi (ibid., 67).

Romanens fortællinger om den ensomme Jespers seksuelle oplevelser på thailandske bordeller i sin tidlige ungdom får ham imidlertid ikke til at fremstå som en 'eventyrlysten' og seksuelt nysgerrig figur, men tværtimod som en mand med 'perverse' seksuelle lyster - noget der samtidig sætter et aftryk på forholdet til Sanne, og får Jespers fascination af hendes krop til at fremstå som en sygelig fetich. Når Jesper beskrives som en ensom særling med et 'outreret' begær underminerer det med andre ord forholdet til Sanne, idet det samtidig antydes, at det er Jespers 'fordrejede' personlighed og 'perverse' begær, der giver ham hans 'mærkværdige' lyst til Sannes tykke krop.

Foruden forholdet til Jesper fylder Sannes erindringer om forældrenes skilsmisse meget. Det bliver således et både tidsligt såvel som følelsesmæssigt brydningspunkt for Sanne, da moren forlader faren til fordel for hans bedste ven, som hun har haft en affære med og faren efterfølgende svigter Sanne, fordi han, begravet i sorg over bruddet, ikke magter hende. Tilbageblikkene på den temmelig triste og ind $\mathrm{i}$ mellem også turbulente barndom kommer (som med Jesper) let til at tjene som psykologisk og altoverskyggende forklaringsmodel for hele Sannes person og liv - og i særdeleshed for hendes 'problem': hendes krop. Beskrivelserne af Sannes barndom understøtter således en indlejret logik om, at krop og sjel har et naturligt sundt og neutralt leje, men at Sannes tykke krop desværre signalerer, at hun er ude af balance. Sanne er således ikke bare tyk, fordi hun ønsker at være det, men er 'endt' sådan, fordi hun har dybe ar på sjælen. En sådan logik truer dermed med at reducere Sannes høje vægt, hidsige temperament og vrede til sygdomstegn og gør den tykke krop til et abnormt symbol på skjulte problemer, der, hvis de blev behandlet, ville forsvinde. 
Som da Sanne genkalder sig en tur på stranden med sine forældre inden de blev skilt. Hvordan de ovenpå et af hendes vredesudbrud over en ødelagt leg fastholdte hende med magt, bar hende ned til vandet og afkølede hende i det og efterfølgende svøbte hende $\mathrm{i}$ håndklæder. Fortællingerne om den vrede barne-Sanne, der bliver ustyrlig og hidsig, når hun ikke făr sin vilje, binder sig an til fortællinger om hendes voksenliv, i hvilke hun på samme vis overmandes af vreden, råber, skriger og slår vildt omkring sig, når noget synes at gå hende imod. Som når hun uden held på posthuset forsøger at afmelde sig modtagelsen af reklamer, når hendes læge behandler hendes hæmorider, eller her, hvor Sanne oplever problemer med at bestille en togbillet ved hjælp af DSB's telefoniske selvbetjeningsautomat:

Metalsmagen får det til at vende sig i hende. Hun spytter ned i sin kaffekop.

Vi har ikke modtaget noget indtastning og afbryder derfor opkaldet.

- FUUUCK! skriger hun og slår telefonen ned i sofabordet.

Hun løfter røret op til øret igen.

- HALLO! skriger hun ind i røret.

We are not registering your response, this call will be cancelled.

Mobilen smadrer, da hun kyler den ind i væggen (ibid., 99).

De mange ofte helt umotiverede vredesudbrud, der dukker op på siderne mellem Sannes tilbageblik på barndommen, flyder sammen og truer med at reducere hende til fusionen af (endnu) to velkendte stereotyper: Barnet (der uden sans for rimelighed og proportioner grådigt kræver mere og mere) og Den hysteriske kvinde (som er helt urimelig og ude af stand til at kontrollere sig selv og lægge bånd på sin krop). Af den grund kommer Sanne let til at fremstå som Freuds prototype på 'Den hysterisk kvinde' og med beskrivelserne af hendes krop, sexliv og parforhold i tillæg; som fan- get i sin egen vrede og langsomt døende krop og som et offer for sin kxrestes perverse og sygelig seksualitet.

Selvom modstand ikke behøver tage form af hverken bevidste eller overlagte handlinger for at kunne tolkes som kritik, så truer beskrivelserne af Sannes mange raserianfald alligevel med at udviske min reparerende læsning af hende. Det sker blandt andet, fordi Sannes vrede let kan afskrives som subjektive følelsesudbrud udløst af hendes hidsige og sygelige natur fremfor en reaktion på og kritik af den verden, der omgiver hende - og som gør hende vred. En reparativ læsning finder som bekendt sted på trods af modsatrettede og nogle gange problematiske (mod)fortællinger. Fortællingen om Sanne er heller ingen undtagelse: Det kræver således en 'reparerende' vilje til at læse henover nogle ret uskønne og stereotype fremstillinger af den tykke krop. Min reparerende læsning af Sanne er da muligvis skrøbelig, men finder trods alt en modstemme i Sannes (både bevidste og ubevidste) forsøg på at yde modstand. Ikke mindst når det handler om hendes omgivelsers opfordringer til at tabe sig, 'blive sund', leve længere og måske oveni købet få børn. Sanne synes således ganske uinteresseret i samfundsmæssige krav om en lykkelig fremtid og et langt liv - en pointe, som psykoanalytiske queerteoretiker Lee Edelmans begreb queer futurisme muligvis kan bidrage til.

\section{ET FALD AF SORT}

Med sin svært pessimistiske bog No Future - Queer Theory and the Death Drive (2004) retter Edelman en heftig kritik af den fremtidstankegang, som han med begrebet $r e$ produktiv futurisme kalder den heteronormative ideologi, der har gjort Barnet til symbolsk figur og orienteringspunktet for al politisk tænkning. Ifølge Edelman har umuligheden af at begribe en fremtid uden Barnet, gjort det til "the telos of the social order (Edelman 2004, 11)" og "the per- 
petual horizon of every acknowledged politics, the fantasmatic beneficiary of every political intervention (Ibid., 3). Edelman hævder således, at en altoverskyggende fantasi om det uskyldsrene Barn, sammen med forestillingen om at det skulle være bæreren af selve fremtiden, har tildelt Barnet en privilegeret position $\mathrm{i}$ den sociale orden og gjort det til det ultimative symbol på succesfuld reproduktion. Den succesfulde reproduktion handler imidlertid ikke alene om konkret menneskelig regenerering, men også om en 'vellykket' reproduktionen og videreførelse af eksempelvis (heteronormative) traditioner, værdier, historisk betydning, normer og kulturel mening. Reproduktiv futurisme er dermed også en fastholdelse af fortiden i fremtiden, hvorfor det at værne om og ofre sig for det evige omdrejningspunkt $\mathrm{i}$ form af Barnet også altid må forstås som et forsøg på at opretholde en politisk status quo. Ifølge Edelman er moderne politisk retorik og handling så gennemsyret af fantasien om Barnet, at det er blevet en decideret umulighed at være imod Barnet, hvis man ellers samtidig vil gøre sig forhåbning om at forblive et genkendeligt subjekt inden for et vestligt politisk tankesystem (Ibid., 3). Barnet og den reproduktive futurisme er dermed også voldelige konstruktioner, der kvæler og lukker ned for alternative fremtider og politiske handlemuligheder, hvorfor Edelman simpelthen foreslår fuldstændigt at undergrave og ødelægge den gældende samfundsorden:

Fuck the social order and the Child in whose name we're collectively terrorized, fuck Laws both with capital $l s$ and with small; fuck the whole network of Symbolic relations and the future that serves as its prop (Ibid., 29).

Et muligt våben i kampen mod Barnet er queerness, som Edelman beskriver som den reproduktive futurismes dualistiske modsætning og nemesis. Inspireret af Jacques
Lacans strukturalistiske psykoanalyse peger Edelman på, at forestillingen om Barnet er en både foranderlig og ufuldkommen konstruktion - et faktum som den sociale orden konstant prøver at dække over gennem forsøg på at stabilisere dets mening. Stabiliseringen sker blandt andet ved at tilskrive (alt det Barnet ikke er:) død, ødelæggelse, perversion og degeneration den queer figur, hvorved queerness:

names the side of those not 'fighting for the children,' the side outside consensus by which all politics confirms the absolute value of reproductive futurism" (ibid., 3 ).

Fremfor at benævne en identitetskategori, er queer således i stedet det, der konstant udgrænses, idet queerness, ifølge Edelman: "never define[s] an identity; it can only ever disturb one" (ibid., 17).

Sanne kan ses som et sådant forstyrrende queer element i romanens fortælling om det at leve. Omkranset og til dels udgjort af fortællinger om død, sorg, angst, vrede, (kropslig) ødelæggelse, opløsning, sygdom og raseri peger Sanne så at sige 'ingen steder hen' og da slet ikke i retningen af en reproduktiv fremtid:

- Måske i nat, hvisker [Jesper] og lægger en hånd på hendes mave.

Hun nikker og tænker, at hendes vægt formentlig arbejder til hendes fordel. Hun vil helst, at det bare er de to. Jespers forventningsfulde blik vil med tiden blive bebrejdende. Hun forestiller sig, at hun kan leve med det. I bytte for sin manglende reproduktion (Holst 2012, 77).

Sanne bliver imidlertid hen mod slutningen af fortællingen gravid, men vælger en abort. Hendes far, der langsomt dør i stueetagen, mens Sanne, Jesper og den øvrige familie venter, er yderligere et dystert element, der griber ind i fortællingen om Sanne og skaber hende som en figur overassocieret med død og sygdom. I kontrast til Sannes anti- 
reproduktive krop står blandt andet hendes mor og Sannes to papsøstre, som med deres slanke, høje, solbrune og elegante kroppe tilsammen udgør fortællingen om en ny, levedygtig og lykkelig familie, der tydeligt peger fremad i retning mod fremtiden og den succesfulde reproduktion af gxldende normer for familieliv, kropslighed og kvindelige skønhedsidealer. Sanne bliver da til en queer figur konstant på tværs af fortællingen om den lyse, gode og bedre fremtid. Hendes familie og Jesper skubber på fremad mod lykken - men Sanne synes ikke interesseret $i$ at deltage og yder modstand. Som her, hvor en misforståelse mellem Sanne og hendes onkel afslører, at Sanne venter på døden, ikke barnet:

- Hvordan har Mikkel det, spørger hun.

Onklen nikker.

- De venter sig jo, siger han. [...]

- Og hvad med dig, spørger onklen.

Sanne flytter sig væk fra rækværkets fugtige belægning.

- Vi venter, siger hun.

- Nu skal I ikke vente for længe.

Hun ser spørgende på ham. Hans ansigt er alvorligt, han trækker på skuldrende.

- Du er jo ikke helt ung længere.

Hendes blik flakker.

- Jeg mener Peter [faren], siger hun, vi går bare og venter... på Peter (Ibid., 172-173).

Sanne er ikke for Barnet - hverken det konkrete i hendes krop eller de fantasier om det, der underbygger samfundsstrukturer, som skubber individer $i$ retningen af bestemte livsmønstre. Sanne drømmer ikke om moderskabet, kernefamilien eller et langt og sundt liv. I stedet ser hun et potentiale $\mathrm{i}$ altings opløsning og $\mathrm{i}$ det sorte mørke:

[Faren] krævede, at Sanne anstrengte sig, koncentrerede sig om at se noget mere end det umiddelbart synlige.

- Jo mørkere, jo tydeligere, belærte han hende.
Han skubbede hende. Vrissede af det oplagte. Der findes øjeblikke, lige inden hun sover, hvor alt styrter. Det genkendelige smadres. Et fald af sort. Det fortalte hun ham, om det sortes potentiale, om altings opløsning (Ibid., 159).

Sanne har af sin far lært om potentialet gemt i mørket - i stedet for at afskrive 'altings opløsning' som en problematisk tilstand, der for alt i verden må undgås, opsøger Sanne øjeblikke, hvor 'alting styrter'. Med romanens skildring af Sannes uregerlige krop, farens forfald og de tos fascination af 'sortheden' kredser fortællingen om død, kaos og sorg og peger således på en anderledes fremtid end den reproduktive. Disse temaer giver imidlertid også anledning til diskussioner om, hvilke narrativer om og representationer af tykke kroppe, der overhovedet er mulige? Om rimeligheden af, at reparative læsestrategier tilsyneladende er nødvendige for at få den tykke krop til fremstå som andet end grænseoverskridende, pervers og syg? I et mere paranoidt perspektiv peger romanens fortælling om Sanne således også på en uretfærdighed og et grundlæggende samfundsmæssigt problem i vores forhold til tykke kroppe, nemlig den, at det ikke synes muligt at læse og skrive den tykke kvindekrop frem som andet end en kropslig fiasko, der må og skal forandres, hvis den vil genkendes som en del af fællesskabet - det levedygtige såvel som det (sundheds)politiske. De mørke og ildevarslende beskrivelser af Sannes krop og liv rejser dermed spørgsmålet om, hvordan det overhovedet er muligt at fortælle om og tænke tykke kroppe.

Med hjælp fra Edelman kan læsningen af Sanne som en queer figur, der aktivt og bevidst modsætter sig krav om en lykkelig fremtid, imidlertid fastholdes - en læsemulighed, der åbner op for muligheden af at tolke Sanne som en feministisk glædesdræber, som ikke blot gennem politiske ytringer og vrede læserbreve forsøger at ødelægge den gode stemning, men som på 
langt mere håndgribelig, anarkistisk og korpulent vis forsøger at modsætte sig samfundsmæssige normer for kropslighed samt de forestillinger om den glæde, der efter sigende skulle følge med i kølvandet på den slanke og reproduktive krop.

Når Probyn, som beskrevet indledningsvis, derfor kritiserer, hvad hun kalder for identitetspolitiske forsøg på 'normalisere' den tykke krop, overser hun således en vigtig pointe: At ikke alle politiske strategier, og slet ikke queerpolitiske, nødvendigvis har til formål at erobre og sikre sig en plads inden for normens grænser - tværtimod. I stedet synes Sanne opsat på at udnytte sin allerede tildelte abjekte position i forsøget på helt at undergrave det normsystem, der diskvalificerer hendes tykke krop og afviser hendes kritik som følelsesladet, misforstået og fejlrettet subjektiv vrede. Med denne læsning bliver Sannes krop da til som ét stort protesttegn og som en helt konkret, og ikke spor metaforisk, politisk kampplads. Sannes krop er en Edelmansk fuck-finger til systemet og alle dets gode intentioner om optimering og livskvalitet.

At jeg har anvendt Ahmeds feministiske glædesdræber sammen med Edelmans vrede protester over Barnet i en reparerende læsning, der har til formål at tilbyde Sanne som en mere 'positiv' figur, vil i bagkloglysets klare skær næppe falde i de tos smag. Ikke desto mindre er det hvad en mindre paranoid læsning af Sanne blandt andet kan tilbyde: en læsning, der forvandler den tykke figurs kropslige 'fiasko' til en queer strategi og genskaber Sanne som et politisk subjekt med agens og vilje. Jeg har således været mindre optaget af at kunne bekræfte og validere Ahmeds og Edelmans teoretiske pointer, og mere optaget af, hvordan inddragelsen af deres respektive politiske strategier sammen med en mere reparerende læsning, kan åbne op for andre perspektiver, spørgsmål og (anderledes) kritiske læsninger end en 'queer-klassisk' paranoid analysestrategi kan.

\section{Noter}

1. Se også Hemmings (2005) og Bissenbakker (2014).

2. Med "'traditionelt' kropspositivt" henviser jeg her til aktivistiske og sociale bevægelser såsom The Fat Acceptance Movement, The Body Positive og Fat Liberation, der hver på sin måde forsøger at bidrage til mere positive representationer af tykke kroppe i håbet om at mindske stigmatisering og diskrimination.

3. Læserbrevene brugt i Sort er skrevet af Holst selv under dæknavnet "Sanne Jensen, Vesterbro" og bragt i Dagbladet Information. I romanen blandes fiktion og dokumentarisme yderligere gennem Holsts brug af billeder fra sin egen opvækst samt $\sin$ fars sygejournal.

4. Denne betegnelse referer her til forholdet mellem to personer, hvori den ene (the feeder) 'fodrer' eller mader den anden (the feedee eller the gainer) med det formål at opnå dels seksuel ophidselse og dets vægtforøgelse. For en uddybelse se $\mathrm{fx}$ Richardson (2010), kapitel 4: “'Watch me Grow!' Fat Admiration, Stuffing and Feederism".

5. Se fx Murray (2004), hvori Murray blandt andet stempler feederism som en misogyn praksis og i øvigt sidestiller den med det at skabe et monster. 6. Se fx kapitel 21: "Overvægt og fedme" i Folkesundhedsrapporten Danmark 2007 udgivet af Statens Institut for Folkesundhed, som blandt andet konkluderer, at der "er klar sammenhæng mellem fedme og uddannelsesniveau. Jo færre antal års uddannelse desto større forekomst af fedme" (s. 264, lokaliseret den 22. november 2016:

http://www.si-folkesundhed.dk/Udgivelser). Omvendt viste en omfattende amerikansk undersøgelse publiceret i The Lancet (2013), at forekomsten af 'fedme' er forbavsende ens på tværs af samfundslag og desuden steget med omtrent samme hastighed gennem årene.

\section{LITTERATUR}

- Ahmed, S. 2010. The Promise of Happiness.

Durham \& London: Duke University Press. - Asbill, D. L. 2009. 'I'm Allowed to Be a Sexual Being': The Distinctive Social Conditions of the Fat Burlesque Stage. In: Rothblum, E.D. and Solovay, S. eds. The Fat Studies Reader. New York: New York University Press.

- Bacon, L. 2010. Health at every size: The surprising truth about your weight. BenBella Books. - Bissenbakker, M. 2014. How to bring your 
daughter up to be a feminist killjoy: Shame, accountability and the necessity of paranoid reading in Lene Kaaberbøl's The Shamer Chronicles. European Journal of Women's Studies. 16(01).

- Bordo, S. 1993. Unbearable Weight: Feminism, Western Culture, and the Body. Berkeley: University of California Press.

- Butler, J. 1993. Bodies that Matter. New York \& London: Routledge.

. Edelman, L. 2004. No Future - Queer Theory and the Death Drive. Durham \& London: Duke University Press.

. Cooper, C. 2010. Fat Studies: Mapping the Field. Sociology Compass. 4(12), 1020-1034. . Foucault, M. 1994. Viljen til viden. Frederiksberg: Det lille Forlag.

- Grosz, E. A. 1994. Volatile Bodies: Toward a Corporeal Feminism. Bloomington and Indianapolis: Indiana University Press.

- Hemmings, C. 2005. Invoking Affect. Cultural theory and the ontological turn. Cultural Studies. 19(5), 548-567.

. Holst, K. H. 2012. Sort. København: Rosinante \& Co.

- Koivunen, A. 2013. Yes We Can? The Promises of Affect for Queer Scholarship. Kvinder, køn \& forskning. 22(3-4), 19-30.

- Vinder, K. 1975. Kvinde kend din krop-en håndbog. København: Tiderne Skifter.

- LeBesco, K. 2004. Revolting Bodies? The Struggle to Redefine Fat Identity. Amhurst and Boston: University of Massachusetts Press.

- Lupton, D. 2013. Fat. London: Routledge. - Lykke, N. 2008. Konsforskning - en guide til feministisk teori, metodologi og skrift. København: Samfundslitteratur.
- Murray, S. 2004. Locating Aesthetics: Sexing the Fat Woman. Social Semiotics, 14(3), 237-247.

- Murray, S. 2008. The 'Fat' Female Body. UK: Palgrave Macmillan.

- Probyn, E. 2008. Silences Behind the Mantra:

Critiquing Feminist Fat. Feminism \& Psychology. 18(3), 401-404.

. Pyle, N. C. and Loewy, M. I. 2009. Double stigma: Fat men and their male admirers. In: Rothblum, E.D. and Solovay, S. eds. The Fat Studies Reader. New York: New York University Press.

- Richardson, N. 2010. Transgressive Bodies: Representations in Film and Popular Culture. Farnham: Ashgate Pub.

- Rosenbeck, B. 2006. Kroppens politik. Forum for idret. 22, 105-109.

- Sedgwick, E. K. 1985. Between Men: English Literature and Male Homosocial Desire. New York: Columbia University Press.

- Sedgwick, E. K. 1990. Epistemology of the Closet. Berkeley \& Los Angeles: University of California Press.

. Sedgwick, E. K. 2003. Touching Feeling: Affect, Pedagogy, Performativity. Durham and London: Duke University Press.

- Søndergaard, D. M. 1996. Tegnet på kroppen: køn: koder og konstruktioner blandt unge voksne $i$ Akademia. København: Museum Tusculanums Forlag.

- The Lancet 2013. Global, regional, and national prevalence of overweight and obesity in children and adults during 1980-2013: a systematic analysis for the Global Burden of Disease Study 2013. The Lancet. 384(9945), 766-781. 


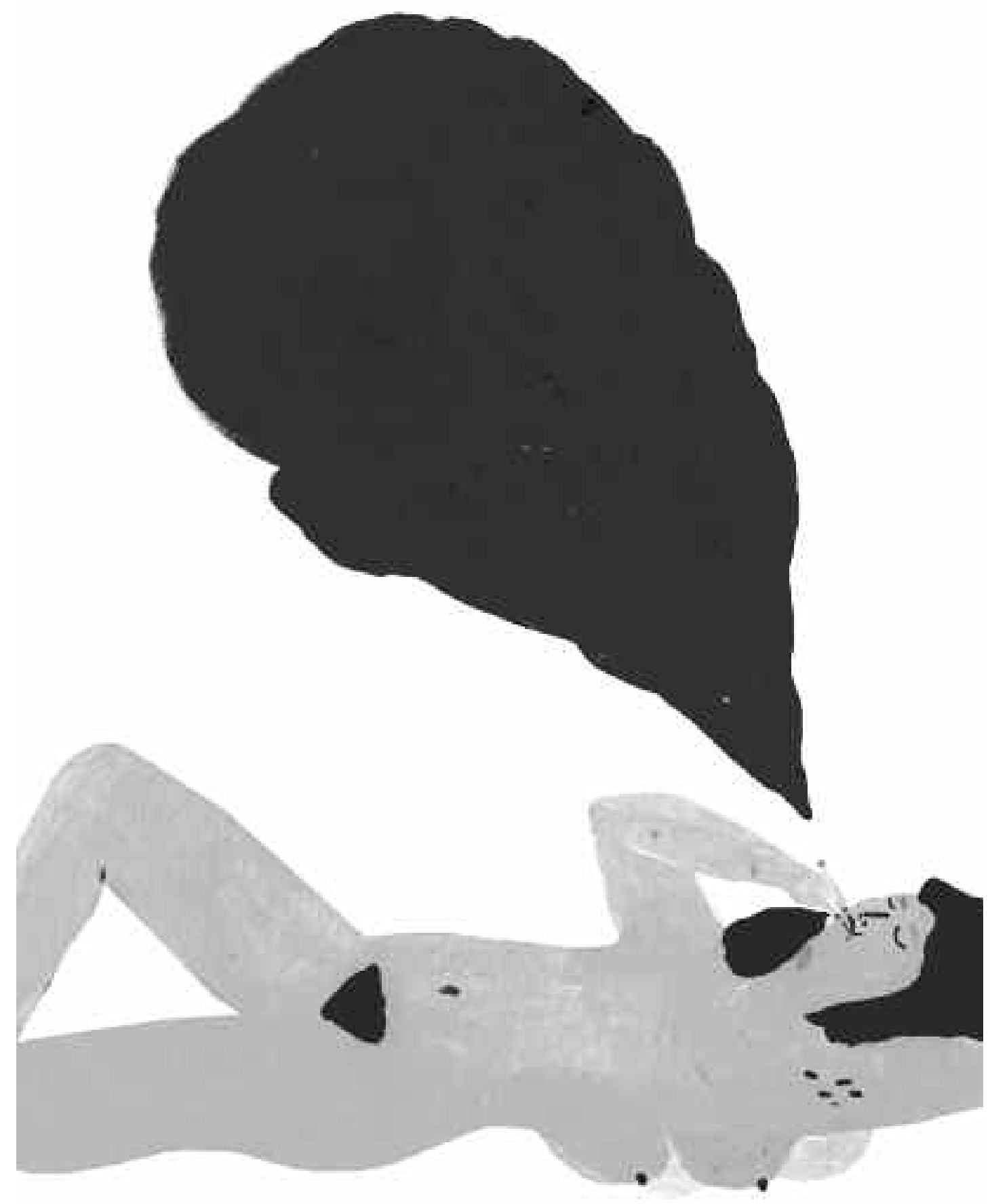

Clara Selina Bach: Smoking Lady, gouache, behandlet digitalt, www.claraselinabach.com. 


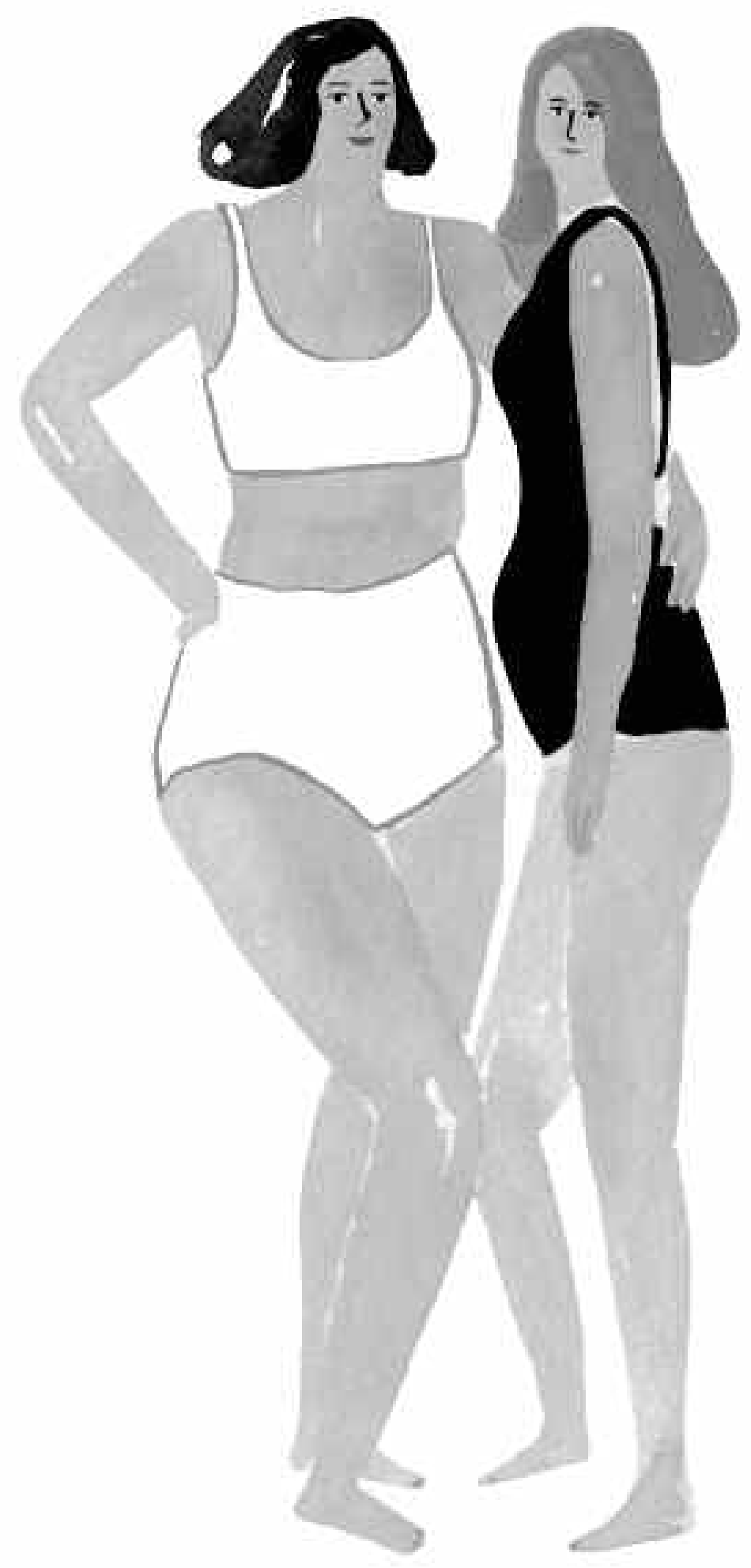

Clara Selina Bach: Girls, gouache, behandlet digitalt, www.claraselinabach.com. 


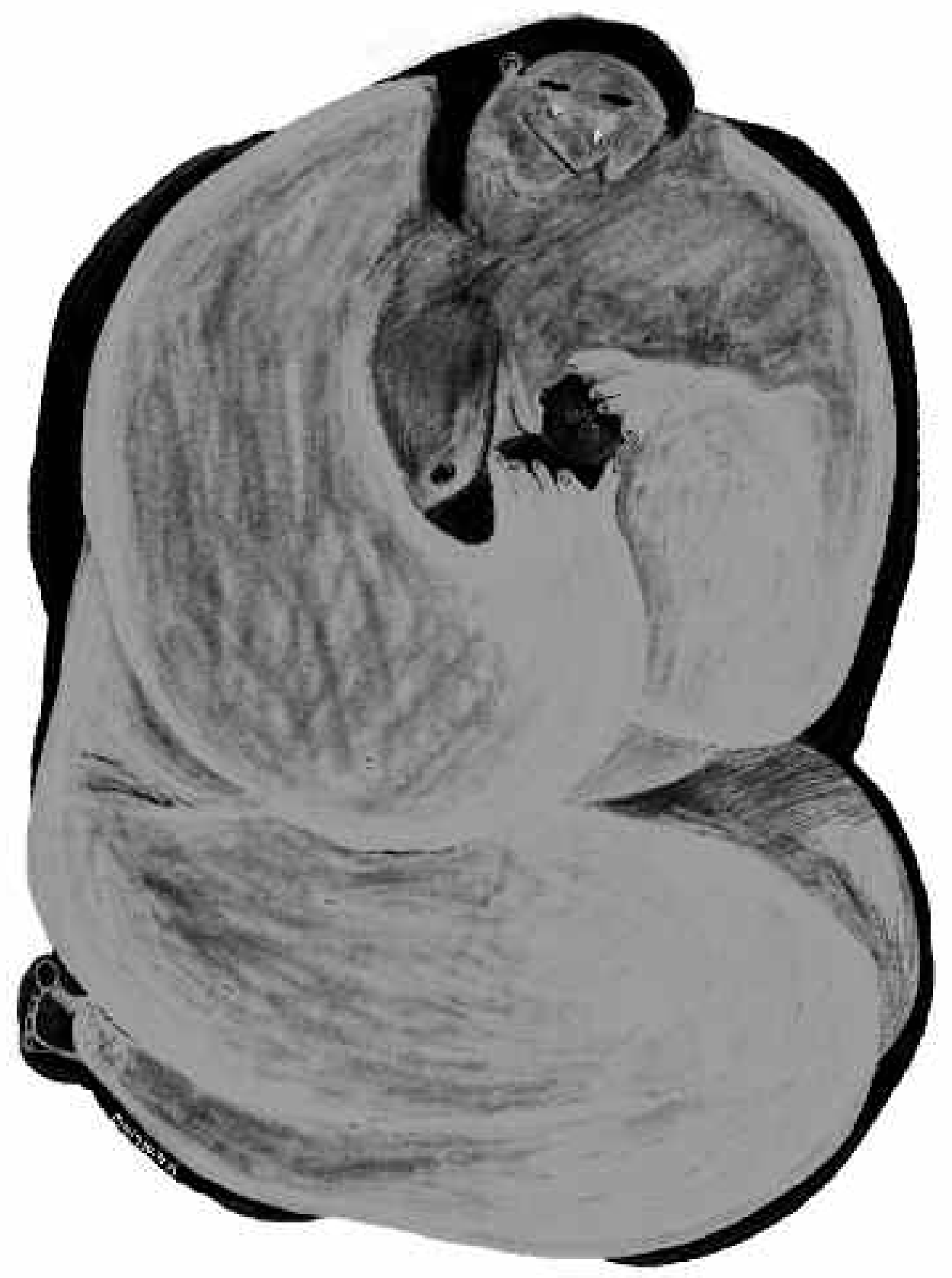

Molly Wittus: Mor og krop, akvarel, behandlet digitalt, www.mollywittus.com 